\title{
Geometrik Düşünme Alışkanlıklarına Yönelik İnançlar: Bir Ölçek Geliştirme Çalışması ${ }^{1}$
}

\section{Buket Özüm Bülbül²}

\section{Bülent Güven ${ }^{3}$}

Type/Tür:

Research/Araştırma

Received/Geliş Tarihi:

October 20/20 Ekim 2020

Accepted/Kabul Tarihi:

January 30/ 30 Ocak 2021

Page numbers/Sayfa No: 886-

905

Corresponding

Author/İletişimden Sorumlu

Yazar:

cbuketozum@gmail.com

\section{$\checkmark$ iThenticate}

This paper was checked for plagiarism using iThenticate during the preview process and before publication. / $\mathrm{Bu}$ çalışma ön inceleme sürecinde ve yayımlanmadan önce iThenticate yazılımı ile taranmıştır.

Copyright $(\subset) 2017$ by Cumhuriyet University, Faculty of Education. All rights reserved.

\begin{abstract}
Öz
Bireylerin düşünme alışkanlıkları, bir problem ile karşılaşıldığında harekete geçer. Geometrik düşünme alışkanlıkları da bunlardan biridir. Geometrik düşünme alışkanlıkları, bireylerin bir geometri problemi ile karşılaştığında problemin çözümüne yönelik ortaya koydukları yaklaşımları içermektedir. Bu yüzden problem çözme ve geometrik düşünme alışkanlıkları iç içedir. Geometrik düşünme alışkanlıklarına yönelik inançlar ise bireylerin bu alışkanlıkları ve problem çözme başarılarını etkilemektedir. Bu sebeple geometrik düşünme alışkanlıklarına yönelik inançların belirlenmesi, geometri derslerinin bu inançlar çerçevesinde şekillendirilmesini ve dolayısıyla geometri başarısının artırılmasını sağlayabilir. $\mathrm{Bu}$ hipotezi test edebilmek ise her şeyden önce bir ölçme aracını gerekli kılmaktadır. Bu çalışmada geometrik düşünme alışkanlıklarına yönelik bir inanç ölçeğinin geliştirilmesi amaçlanmıştır. Bu amaç doğrultusunda geliştirilmesi istenen ölçek bir devlet üniversitesinde öğrenim gören 296 matematik öğretmeni adayına uygulanmıştır. Ölçeğin geliştirilmesi aşamasında açımlayıcı faktör analizi ve doğrulayıcı faktör analizi yapılmıştır. Çalışmanın sonucunda 22 maddeden ve ön hazırlık inancı, pes etmeme ve azim ile farklı çözüm stratejileri inancı olmak üzere 3 boyuttan oluşan geometrik düşünme alışkanlıklarına yönelik bir inanç ölçeği elde edilmiştir. Elde edilen ölçeğin tamamının Cronbach Alpha güvenirlik katsayısı .88 bulunmuştur. Alt boyutların Cronbach Alpha güvenirlik katsayıları ise sirasiyla .82 .89 ve .85 şeklinde hesaplanmıştır. Hem açımlayıcı faktör analizinden hem de doğrulayıcı faktör analizinden elde edilen sonuçlar, literatür ile desteklendiğinden ölçeğin kabul edilebilir düzeyde olduğunu göstermektedir. Dolayısıyla bu çalışma ile geometrik düşünme alışkanlıklarına yönelik 6'sı olumsuz toplam 22 maddeden oluşan bir ölçek geliştirilmiştir. Bu çalışmadan elde edilen sonuçlar literatürle tartışılmıştır.
\end{abstract}

Anahtar Kelimeler: Düşünme alışkanlığı, geometrik düşünme alışkanlığı, ölçek geliştirme, inanç, geometri

\section{Suggested APA Citation/Önerilen APA Atıf Biçimi:}

Bülbül, B.Ö., \& Güven, B. (2021). Geometrik düşünme alışkanlıklarına yönelik inançlar: Bir ölçek geliştirme çalışması. Cumhuriyet International Journal of Education, 10(2), 886-905. http:/ / dx.doi.org/10.30703/cije.813168

\footnotetext{
${ }^{1} \mathrm{Bu}$ çalışma birinci yazarın doktora tezinden üretilmiştir.

2 Dr. Öğr. Üyesi, Manisa Celal Bayar Üniversitesi, Eğitim Fakültesi, Matematik ve Fen Bilimleri Eğitimi Bölümü, Manisa/ Türkiye

Asst. Prof., Manisa Celal Bayar University, Faculty of Education, Department of Mathematics and Science Teaching, Manisa/Turkey

e-mail: cbuketozum@gmail.com ORCID ID: orcid.org/0000-0001-9610-7053
}

${ }^{3}$ Prof. Dr., Trabzon Üniversitesi, Fatih Eğitim Fakültesi, Matematik ve Fen Bilimleri Eğitimi Bölümü, Trabzon/Türkiye Prof. Dr., Trabzon University, Fatih Faculty of Education, Department of Mathematics and Science Teaching, Trabzon/Turkey e-mail: bguven@trabzon.edu.tr ORCID ID: orcid.org/0000-0001-8767-6051 


\title{
Beliefs about Geometric Habits of Mind: A Scale Development Study
}

\begin{abstract}
When individual encounter a problem, their habits of mind take action. Geometric habits of mind are one of these habits of minds. Geometric habits of mind refers to the approach of individuals to the solution of the problem when they encounter a geometry problem. Therefore problem solving and geometric habits of mind are intertwined. Beliefs about geometric habits of mind affect individuals' geometric habits of mind and problem solving success. First of all, a measurement tool is required to test this state. This situation create individuals to be successfull in geometry. Therefore, in this study, it is aimed to develop a scale to reveal beliefs about geometric habits of mind. In accordance with this purpose, the developed scale is applied to 296 mathematics prospective teachers. Exploratory factor analysis (EFA) and confirmatory factor analysis (CFA) were performed during the development of the scale. As a result of the study, beliefs of GHoM scale is obtained which consists of 22 items and three dimensions such that preliminary belief, stand firm and resolution and beliefs of different solution strategies. The Cronbach's Alpha reliability coefficient for the complete scale is .92. Cronbach's Alpha reliability coefficients of the sub-factors are calculated as $.82, .89$ and .85 respectively. The results obtained from both EFA and DFA Show that the scale is acceptable. As a result of this study, beliefs about geometric habits of mind scale was developed that consists of 22 items and six of which are negative. The results obtained from the study are discussed in literature.
\end{abstract}

Keywords: Habits of mind, geometric habits of mind, scale development, belief, geometry

\section{Giriş}

Geometri öğretiminde öğrencilere kazandırılmak istenen akıl yürütme, ispat yapma, eleştirel düşünme, yaratıcı düşünme, geometrik yapılar arasında ilişki kurma, geometriyi günlük yaşamda ve farklı disiplinlerde kullanabilme, problem çözme, soyut kavramları somutlaştırabilme şeklindedir birtakım beceriler vardır (Baki, 2008; González ve Herbst, 2006; NCTM, 2000). Söz konusu becerilerin istenilen düzeyde kullanımı, geometri başarısını olumlu ya da olumsuz etkileyebilmektedir. Eğer bu beceriler derslerde etkili bir şekilde kullanılmazsa geometri, öğrencilerin zihninde anlaşılması zor ve karmaşık bir ders olarak kalacaktır.

Matematik ve geometri öğretiminde yukarıda bahsi geçen becerilerin merkezinde problem çözme becerilerinin olması gerekliliği pek çok araştırmacı tarafından vurgulanmıştır (Baki, 2008; Soylu ve Soylu, 2006). Problem çözme becerisi, karşılaşılan zorlukların üstesinden gelebilme yeteneği olarak da tanımlanabilir. Eğitimin öncelikli hedeflerinden birinin de karşılaştı̆̆ gelebilen bireylerin yetiştirilmesinin olması problem çözme becerilerinin bireylere kazandırılmasa yönelik vurguyu artırmaktadır (NCTM, 2000; Soylu ve Soylu, 2006). Bireyler öğrenme sürecinde problem çözerken bazı zihinsel alışkanlıkları kullanma eğilimine girer. Literatürde düşünme alışkanlıkları olarak ifade edilen bu alışkanlıklar; bireylerin çözümüne doğrudan ulaşamadığ1 problemle karşılaştığında, problemin üstesinden gelme eğilimi olarak ifade edilmektedir (Costa ve Kallick, 2000; Jones, 2014). Geometride başarılı olabilmek için, iyi bir problem çözücü olmanın yanında bazı düşünme alışkanlıklarına da sahip olmak gerekir. Geometrik düşünme alışkanlıkları (GDA) olarak ifade edilen bu alışkanlıklar, bireylerin problem çözme sürecinde işe koyduğu çözüm yönelimleridir de denilebilir. Yani bireyler bu GDA'lara ne kadar iyi 
sahip olursa, geometri başarısında ve geometri problem çözme sürecinde o derece başarılı olacaktır (Bülbül ve Güven, 2019, Bülbül ve Güven, 2020; Driscoll, DiMatteo, Nikula ve Egan, 2007; Driscoll, DiMatteo, Nikula, Egan, Mark ve Kelemanik, 2008). Ancak bazı durumlarda bireyler söz konusu alışkanlıklara iyi derecede sahip olsalar da istenilen geometri başarısını elde etmede zorlanabilmektedir. İşte bu aşamada öğrencilerin GDA'lara yönelik inançları devreye girmektedir. Yani öğrenciler, GDA'ları ne kadar üst düzeyde kullanırsa kullansın, problem çözmeye yönelik inançları ve istekleri azaldıkça bu alışkanlıkları kullanım düzeyi de o ölçüde azalacaktır (Driscoll vd., 2007). Bu bakımdan öğrencilerin düşünme alışkanlıklarına yönelik duyuşsal boyuttaki inançlarının ortaya çıkarılması, düşünme alışkanlıklarının gelişim boyutunda önemli yer edinmesini sağlayacaktır. Dolayısıyla geometri başarısında ve GDA'ların etkili kullanımında rolü olan bu inançlar oldukça önemli olmasına rağmen, ilgili literatürde GDA inançlarını belirlemeye yönelik bir veri toplama aracına rastlanmamıştır. Hem öğrencilerin geometri başarısını etkileyen bu faktörleri ortaya çıkarabilmek hem de ilgili literatürdeki eksikliği kapatabilmek amacıyla bu çalışma yürütülmüştür.

\section{Geometrik Düşünme Alışkanlıkları ve Problem Çözme}

Düşünme alışkanlıkları, karşılaşılan bir problemin çözüm yolunun bilinmediği durumlarda devreye giren ve çözüm sürecinde bireye yol gösterici düşünme yöntemleridir (Costa ve Kallick, 2000). Lim ve Selden (2009) düşünme alışkanlıklarını genel ve alana özgü düşünme alışkanlıkları olarak ikiye ayırmıştır. Genel düşünme alışkanlıkları, bireylerin karşılaştığı problemin çözümüne yönelik ilişki arama, deneyim kazanma, denemeler yaparak bir sonuca ulaşmaya çalışma gibi yaklaşımları içermektedir. Alana özgü düşünme alışkanlıkları ise geometrik, matematiksel, olasılıksal, cebirsel, analitik, bilimsel düşünme alışkanlıkları gibi bir disipline yönelik alışkanlıklardır. Bu çalışmada GDA'lara yönelik inançlar temel alındığından daha çok bu kapsama değinilmiştir.

Genel olarak GDA, denemeler yaparak doğru sonuca ulaşabilme, keşfetme ve yansıtma, uç durumları düşünebilme, değişmezleri inceleme ilişkilendirme, özel durumları düşünebilme, genellemeler yapma şeklindedir (Bülbül, 2016; Cuoco, Goldenberg ve Mark, 1996; Driscoll vd., 2008; Goldenberg, 1996). Her bir alışkanlığın kullanımına bakıldığında aslında geometrik düşünme alışkanlıkları ile problem çözmenin iç içe olduğu görülmektedir. Yani geometrik düşünme alışkanlıkları öğrenciler bir problemle karşılaştığında, onların çözüme ulaşma yöntemlerini etkilediği ifade edilmektedir. Bu durumda geometrik düşünme alışkanlıkları bireylerin problemi nasıl çözeceğini bilemediği durumlarda problemin çözüm yoluna karar verme sürecidir. Burada cevabın doğrudan görülemediği durumlarda, bireylerin doğru cevaba ulaşma çabaları, onların düşünme alışkanlıkları ile ifade edilmektedir (Costa ve Kallick, 2000; Driscoll vd., 2008; Leikin, 2007; Marzano, Pickering ve McTighe, 1993). Bu kapsamda Jacobbe ve Millman (2009), herhangi bir problem çözme yeteneği olmadan öğrencilerin çözüme başlamasının oldukça zor olduğunu belirtmiş, dolayısıyla öğrencilerin matematiksel ve geometrik düşünme alışkanlıklarının, onların problem çözme süreci içerisinde ortaya çıktığını ve karşılaşılan problemin çözümünde yardımcı olduğunu belirtmiştir. Dolayısıyla geometrik düşünme alışkanlıkları bireylerin doğrudan çözüme ulaşamadığı bir geometri problemi ile karşılaştığında, çözümü nasıl yapacağına yönelik yaklaşım olduğu söylenebilir. 


\section{Geometrik Düşünme Alışkanlıklarına Yönelik İnançlar}

Eğitimde inanç, bireyin çevresindeki olaylara yönelik zihninde geliştirdiği kavrayışlar ve temel varsayımlardır şeklinde tanımlanmaktadır (Richardson, 1996). Dolayısıyla eğitim öğretim ortamlarında öğrencilerin zihninde yer eden kavrayışları olumlu yönde etkilenirse, derslerindeki başarılarını da olumlu yönde etkilenecektir (Ball, 1998; Grouws, 1996; Schoenfeld, 1992; Wilkins ve Brand, 2004). Yukarıda da bahsedildiği gibi öğrencilerin GDA'larının problem çözme ve geometri başarılarını etkilediğini, GDA'lara yönelik inançlarının da söz konusu başarıları etkilediğini söyleyebiliriz. Dolayısıyla bu inançları ortaya çıkaran bir ölçme aracının olması da, öğrencilerin düşünme alışkanlıkları bakımından hangi eğilimde olduklarının anlaşılmasına yardımcı olacaktır.

Öğrencilere geometrik düşünme alışkanlıklarını kazandırmada önemli olan bir diğer boyutta, geometrik düşünme alışkanlıkları çerçevesinde problem çözmeye yönelik inançlardır. Çünkü öğrenciler, geometrik düşünme alışkanlıklarını ne kadar üst düzeyde kullanırsa kullansın, problem çözmeye yönelik inançları ve istekleri azaldıkça bu alışkanlıkları kullanım düzeyi de o ölçüde azalacaktır (Driscoll vd., 2007). $\mathrm{Bu}$ bakımdan öğrencilerin düşünme alışkanlıklarına yönelik duyuşsal boyuttaki inançlarının ortaya çıkarılması, düşünme alışkanlıklarının gelişim boyutunda önemli yer edinmesini sağlayacaktır.

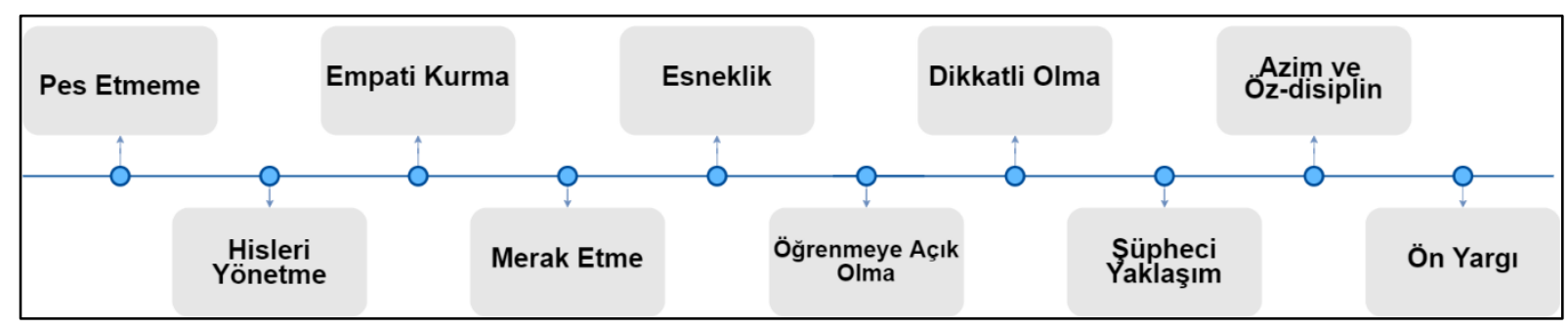

Şekil 1. Geometrik düşünme alışkanlıklarını etkileyen duyuşsal faktörler

Bülbül (2016) geometrik düşünme alışkanlıklarını etkileyen duyuşsal faktörleri Şekil 1'deki öğeler çerçevesinde açıklamıştır (Arisa, 1998; Bailin, 1999; Bergman 2007; Cook, 1996; Coxford, 1998; Cuoco, Goldenberg, ve Mark, 1996; Driscoll vd., 2007; Driscoll vd., 2008; Goldenberg,1996; Richardson, 1996; Sher, 1992; Van Tasselo-Baska, 1998; Volkmann, 1999). Şekil 1 incelendiğinde bu faktörlerin pes etmeme, hisleri yönetme, empati kurma, merak etme, esneklik, öğrenmeye açık olma, şüpheci yaklaşım, azim ve öz dsiplin, ön yarg1 şeklinde olduğu görülmektedir. Bu faktörleri daha ayrıntılandırdığımızda; Bireylerin karşılaştığı poblemleri çözmeye yönelik azmi pes etmeme olarak adlandırılmaktadır. Pes etmeme inancı sayesinde bireyler yapamadığı problemleri farklı yöntemler ile çözme arayışına girmektedir. Birey çözüme ulaşamadığı durumlarda farklı stratejiler deneyerek, ona odaklanmalıdır. Tek bir çözüme ulaşamayınca o problemi bırakmayıp farklı yollar deneyen bir birey pes etmeme alışkanlığına sahiptir. Bireyin problemi çözmeden önce çözüme yönelik tartışma yapması, plan yapması, stratejiler geliştirerek probleme yönelik bilinçlilik duygusunu oluşturması da hisleri yönetme olarak adlandırılmaktadır. Kısacası bir problemi çözmeden önce bireyin o problem üzerinde düşünmesidir. Bazen bireyler karşılaştığ1 problemleri çözemedikleri durumlarda farklı kişilerin çözüm yollarını inceleyerek probleme onların bakıp, başkasının yerine kendini koyarak 
düşünebilmektedir ki bu inanç empati kurma şeklinde adlandırılmaktadır. Bazı durumlarda ise bireylerin karşılaştığı bir problemin çözümünün nasıl olacağını merak ederek o probleme yaklaşması gerekir. Bireyin bir problemi yanlış düşündüğü durumlarda farklı seçeneklerinin de olacağını fark etmesi ve buna bağlı olarak yaptığı çözümü değiştirmesi esneklik olarak isimlendirilmektedir. Bu şekilde birey bir duruma farklı açılardan bakabilir, bir problemi tekrar tanımlayabilir, yeni çözümlere ulaşabilir. $\mathrm{Bu}$ durumda birey problemin tek bir çözümünün olmayacağının bilincindedir. Söz konusu bilinci kazanabilmesi için de bireylerin öğrenmeye açık olması gerekir. Öğrenmeye açık olma, bireyin grup çalışmaları yaparak, bilmediği konularda arkadaşlarından yeni bilgiler öğrenebilmesi, yeni konuları araştırabilme isteğidir. Geometrik düşünme alışkanlıklarını etkileyen faktörlerden bir diğeri de dikkatli olmadır. Dikkatli olma, problemin çözüm sürecinde bireyin yaptığ1 işlemlere dikkat etmesi, yanlış yapma riskini en aza indirebilmesidir. Şüpheci yaklaşım faktöründe verilen bir problemin çözümünün birden fazla olabileceğinin düşünülerek, yapılan çözümün belirli aralıklarla kontrol edilmesidir. Problemlerin etkili ve doğru bir şekilde çözülebilmesi için bireylerin sahip olması gereken inançlarından bir diğerinin de azim ve öz-dsiplin olduğu göze çarpmaktadır. Azim ve öz-dsiplin bireylerin verilen bir problemi çözmeye yönelik inancı ve bu süreçte geometri dilini etkili bir şekilde kullanabilmesini içermektedir. Son olarak ön yargı, bireyin problemi çözmeden önce çözümün zor ya da kolay olacağına dair ön yargısının olmaması gerekir. Aksi takdirde birey bu durumdan etkilenecek ve doğru sonuca ulaşamayacaktır.

Sonuç olarak bireylerin geometrik düşünme alışkanlıklarının geliştirilmesi aşamasında, söz konusu alışkanlıklara yönelik inançlarının ortaya çıkarılması geometri başarılarını da etkilemesinden dolayı önemlidir. Çünkü öğrencilerin sahip olduğu inançlar ortaya çıkarılıp, olumsuz inançlar aza indirgenmeye çalışılırsa onların bilişsel boyuttaki geometrik düşünme alışkanlıkları ve geometri başarıları da olumlu yönde etkilenecektir. Burada unutulmaması gereken nokta GDA'lar ile problem çözme sürecinin iç içe olmasıdır. Dolayısıyla bu çalışma ile matematik öğretmeni adaylarının geometrik düşünme alışkanlıklarına yönelik inançlarını ortaya çıkaran bir ölçeğin geliştirilmesi amaçlanmıştır.

\section{Yöntem}

$\mathrm{Bu}$ çalışma öğrencilerin geometrik düşünme alışkanlıklarının belirlenmesine yönelik hazırlanmış bir ölçek geliştirme çalışmasıdır. Ölçek geliştirme basamakları, ilgili başlıklara göre anlatılmıştır.

\section{Çalışma Grubu}

Ölçek 2013-2014 eğitim öğretim yılı bahar döneminde bir devlet üniversitesinin İlköğretim Matematik Öğretmenliği Programı'nda öğrenim görmekte olan toplam 296 öğretmen adayına uygulanmıştır. Bu çalışmada GDA'lara yönelik inançlarının belirlenmesi amaçlandığından, katılımcılar geometri dersi görmüş olan öğretmen adaylarından seçilmiştir. Ayrıca öğretmen adayları seçilirken farklı sınıflarda öğrenim görmelerine dikkat edilerek maksimum çeşitlilik örnekleme yöntemi kullanılmıştır.

\section{Ölçeğin Geliştirilme Süreci}

Ölçek geliştirirken sırasıyla madde havuzu oluşturma, uzman görüşü alma, faktör analizi ve güvenirlik hesaplama adımları izlenmiştir. Bu bağlamda araştırma için 
gerekli kuramsal verilerin toplanması aşamasında, geometrik düşünme alışkanlıkları ve problem çözmeye yönelik inanç konuları ile ilgili geniş çaplı literatür taraması yapılmıştır (Arisa, 1998; Bailin, 1999; Bergman 2007; Cook, 1996; Coxford, 1998; Cuoco, Goldenberg, ve Mark, 1996; Driscoll vd., 2007; Driscoll vd., 2008; Goldenberg,1996; Richardson, 1996; Sher, 1992; Van Tasselo-Baska, 1998; Volkmann, 1999). Literatür taraması ile çalışmanın kuramsal kısmı olan problem çözme sürecinde kullanılan GDA'lara yönelik inançlar belirlenmiştir. Bahsi geçen inançlara yönelik madde havuzu hazırlanmıştır ve bu aşamada hazırlanan maddelerin amacına uygunluğu sağlanmıştır. Ayrıca madde havuzunda yer alan ifadelerin uzun ve karmaşık maddelerden oluşmamasına, her bir maddenin birden fazla özelliği içermemesine ve ölçülebilir olmasına dikkat edilerek 38 maddenin yer aldığı bir madde havuzu oluşturulmuştur. Ardından oluşturulan madde havuzu, matematik eğitimi alanından, ölçme ve değerlendirme alanından uzmanlar tarafından incelenmiştir. Uzman görüşleri çerçevesinde anlaşılmayan ve ölçülmek isteneni yansıtmayan maddeler yenilenmiştir. Örneğin başlangıçta ölçekte yer alan bir madde "Verilen herhangi bir problemin çözümünde tüm matematikçiler aynı yöntemi kullanmalıdır" şeklinde iken uzman görüşleri doğrultusunda bu madde "Verilen herhangi bir geometri probleminde, herkes aynı yöntemi kullanmalıdır" şeklinde değiştirilmiştir. Bu şekilde inançların daha kapsamlı bir görüşü ifade edeceği düşünülmüştür. Tüm bu işlemlerin sonucunda 38 maddeden oluşan bir taslak ölçek hazırlanmıştır. Taslak ölçekte yer alan maddelerin $8^{\prime} \mathrm{i}$, olumsuz, 30'u olumlu ifadeler içermektedir. Ölçek maddeleri kesinlikle katılıyorum, katılıyorum, kararsızım, katılmıyorum ve kesinlikle katılmıorum şeklinde 5'li Likert tipindedir.

\section{Verilerin Analizi}

Ölçeğin taslak formuna uzman görüşleri doğrultusunda son haline yer verildikten sonra kapsam ve yapı geçerliği incelenmiştir. Kapsam geçerliği, ölçekteki maddelerin hedef alanını ne derece açıklayabildiği ile ilgili uzman görüşü olup, ölçme aracının hedeflenen konunun kapsamını hangi düzeyde temsil edebilmesi açısından önemlidir (Cohen, Manion ve Morrison, 2002). Ölçek geliştirirken, kapsam geçerliği çerçevesinde ölçekte yer alan maddelerin nitelik ve sayı olarak yeterli olup olmadığını belirlemek amacıyla matematik ve geometri eğitimi alanında araştırmalarını yürüten 3 , ölçme ve değerlendirme alanında çalışmalarını yürüten bir uzman görüşüne başvurulmuştur. Yapı geçerliği, ölçme aracının gözlenmek istenen tepkileri uyandırabilme gücü, somut ya da fiziksel olmayan bir olguyu doğru ölçebilmesidir (Bindak, 2005). Bu çalışmada da yapı geçerliliğinin sağlanması amacıyla Açımlayıcı Faktör Analizi (AFA) ve Doğrulayıcı Faktör Analizi (DFA) yapılmıştır. AFA'dan elde edilen sonuçlar ile ölçeği oluşturan faktörler belirlenmiş, her bir faktörün güvenirliği belirlenmiştir. Literatürde ölçek geliştirilirken tek başına AFA'nin yeterli olmadığı için önceden yapılandırılan bu ölçeğin aynı zamanda DFA'da yapılması gerektiği ifade edilmektedir (Hinkin, 1995). Ayrica DFA ile AFA yöntemiyle oluşturulan faktörlerde yer alan değişken gruplarının hangi faktör ile hangi düzeyde ilişkiye sahip olduğu gözlenebilmektedir (Bryant ve Yarnold, 1995). Dolayısıyla bu çalışmada da AFA ve DFA birlikte yürütülmüştür.

SPSS 21.0 paket programı AFA yapılırken kullanılmıştır. Faktör analizi yürütülmeden önce elde edilen verilerin faktör analizine uygunluğuna Kaiser Meyer Olkin Measure of Sampling Adequacy (KMO) katsaysı ve Barlett küresellik testi 
yapılarak karar verilmiştir. KMO katsayısı, veri matrisinin faktör analizinin ve veri yapısının faktör çıkarma için uygunluğu hakkında bilgi verir (Büyüköztürk, 2010). Çalışmada bu değerlere bakılarak ölçeğin faktör analizinin yapılabilirliğine karar verilmiştir. Daha sonra ölçeğin yapı geçerliğini belirlemek amacıyla Varimax döndürme yöntemi ile temel bileşenler analizi kullanılmıştır. AFA sonrasında oluşan yapının uygunluğunun belirlenmesi amacıyla da DFA işlemi uygulanmıştır. DFA işlemi AMOS 21.0 paket programı ile yürütülmüş olup ortaya çıkan uyum ve hata indeksleri incelenmiştir. Ölçeğin güvenirliğin testi için de Cronach Alpha güvenirlik katsayısı hesaplanmıştır. Cronbach Alpha güvenirlik katsayısı ölçeğin hem tamamı hem de alt faktörlere (boyutlara) göre hesaplanmıştır.

\section{Bulgular}

\section{Ölçeğin Geçerlik Çalışmasından Elde Edilen Bulgular}

Bu çalışmada uygulanan ölçeğin AFA'ya uygunluğuna karar verebilmek için Kaiser Meyer Olkin (KMO) katsayısıyla Barlett küresellik testi incelenmiştir. Yapılan analizler sonucunda Kaiser Meyer Olkin (KMO) değeri .901 bulunmuştur. İlgili literatürde KMO değerinin .60 değerinden yüksek olmasının, faktör analizi işlemini gerçekleştirmek için yeterli olduğu ifade edilmiştir (Büyüköztürk, 2010; Field, 2005). Barlett küresellik testi değerinin 1934,552 ve p<0,05 düzeyinde anlamlı olduğu görülmektedir. Barlett küresellik testi de değişkenler arasında ilişki olup olmadığını korelasyonlar bazında inceler. Elde edilen p değeri .10 veya daha üzerindeyse bu verilerle faktör analizi yapmanın uygun olmadığ1 söylenebilir (Büyüköztürk, 2010; Tabachnick ve Fidel, 2001). KMO katsayısının kabul edilebilirliği ve Barlett küresellik testinden elde edilen sonuçların anlamlılı̆̆ı bulgularından yola çıkarak ölçekten elde edilen verilerin, faktör analizi yapmak için uygun olduğu görülmektedir.

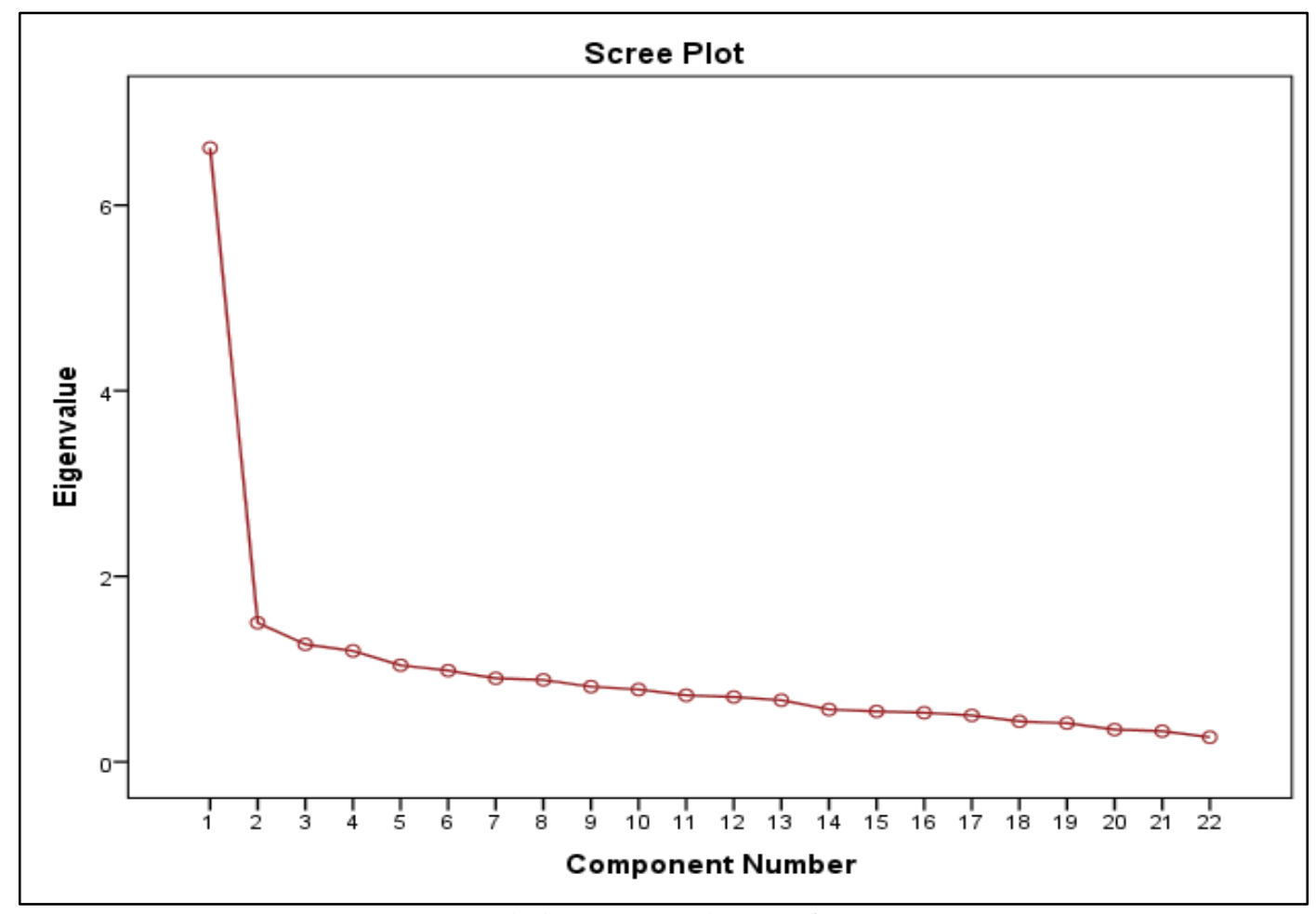

Şekil 2. Scree plot grafiği 
AFA ölçekte yer alan 38 madde üzerinden gerçekleştirilmiştir. Şekil 2'de verilen grafikte yatay eksen faktörleri, dikey eksen ise özdeğer miktarlarını göstermektedir. Grafikte yüksek ivmeli, hızlı düşüşlerin yaşandığı faktör önemli faktör sayısını verir. Yatay çizgiler faktörlerin getirdikleri ek varyansların katkılarının birbirine yakın olduğunu gösterir (Büyüköztürk, 2010). Grafik eğrisinin 3. Faktörden sonra katk1 miktarının az olduğu ve eğrinin azaldığ görülmektedir. Bu değerlerlerin hepsi 1'in üzerindedir. Faktörlerin açıkladıkları varyans yüzdeleri sırasıyla 30.073, 6.815, 5.758 dir. Üç faktörün tamamı, toplam varyansın \% 42.646'sını açıklamaktadır. Açıklanan varyansın \%30'un üzerinde olan bu varyans miktarı, ölçeğin üç faktörden değerlendirmesine olanak verdiği kabul edilebilir. Tablo 1'de faktörlere verilen isimler, bu maddelerin olumlu ya da olumsuz niteliği, hangi maddeleri içerdiği ve döndürme sonrası oluşan yük değerleri verilmiştir.

İkinci aşamada ölçeğin yapı geçerliğini belirlemek amacıyla son halinde yer alan maddelere Temel Bileşenler Analizi-TBA (Principal Component Analysis) yapılmıştır. Kaiser (1960) AFA sonucunda elde edilen faktörlere ait öz değerlerin 1'in üzerinde olması gerektiğini ifade etmiştir. Dolayısıyla bu çalışmada da öz değerleri 1'in üzerinde olan üç faktör altında toplandı̆̆ görülmüştür. Birbirinden bağımsız faktörlere ulaşabilmek için faktör analizinde Varimax dik döndürme metodu kullanılmıştır. Faktör yük değeri 0.30'un altında olan ve birden fazla faktöre girerek aralarındaki faktör yük değerleri farkı 0.10 ve daha az olan 16 madde elenerek toplam 22 maddelik bir ölçek elde edilmiştir. Ayrıca Varimax Faktör Analizi ile yapılan döndürme işlemi sonunda, ölçeğin üç boyutlu olduğuna karar verilmiştir. Tablo 1'de her bir maddenin hangi faktör altında toplandı̆̆ı, maddelere ait faktör yük değerleri, maddelerin açıkladığı ortak varyansları ve maddelerin açıkladığı toplam varyanslarına ait bilgiler verilmiştir.

Büyüköztürk (2010) AFA sonucunda, faktörler tarafından açılanan varyanslar toplamının \%30 ve üzerinin, ölçekteki maddelerin faktör yük değerlerinin de .30 ve üzerinde olmasının yeterli olduğunu ifade etmiştir. Bu kapsamda Tablo 1'de yer alan değerler incelendiğinde toplam 22 maddelik ölçeğin öz değeri 1'den yüksek 3 faktör altında toplandığı, toplam varyansın ise \%42,646'sının açıklandığı görülmektedir. Yine Tablo 2'de verilen maddelerin yük değerlerinin en düşük .30 olduğu gözlenmektedir. Ön hazırlık inancı olarak isimlendirilen birinci faktörde yer alan 11 maddenin (m3, m5, m7, m8, m9, m11, m12, m13, m14, m17, m20) toplam varyansın \%30,073'ünü açıkladığı, bu faktör içerisinde yer alan maddelerin faktör yüklerinin ise en düşük .49, en yüksek .68 değerlerini aldığı söylenebilir. Tablo 1'de pes etmeme ve azim olarak isimlendirilen ikinci faktörde yer alan 5 maddenin (m1, m2, m4, m10, m21) toplam varyansın \%6,815'ini açıkladı̆̆ı, bu faktör içerisinde yer alan maddelerin faktör yüklerinin en düşük .45, en yüksek .78 değerlerini aldığ 1 görülmektedir. Son olarak Tablo 1'de farklı çözüm stratejileri inancı olarak isimlendirilen üçüncü faktörde yer alan 6 maddenin (m6, m15, m16, m18, m19, m22) toplam varyansın \%5,758' ini açıkladığı gözlenir. Ayrıca farklı çözüm stratejileri inancı boyutunda yer alan maddelerin faktör yüklerinin .30 ile .63 arasında değişmektedir. 
Tablo 1

Geometrik Düşünme Alışkanlığına Yönelik İnanç Ölçeği AFA Sonuçları

\begin{tabular}{|c|c|c|c|c|}
\hline & Maddeler & Faktör 1 & Faktör 2 & Faktör 3 \\
\hline \multirow{11}{*}{ Ön hazırlık inancı } & $\mathrm{m} 3$ & .57 & & \\
\hline & $\mathrm{m} 5$ & .64 & & \\
\hline & $\mathrm{m} 7$ & .61 & & \\
\hline & $\mathrm{m} 8$ & .67 & & \\
\hline & $\mathrm{m} 9$ & .68 & & \\
\hline & m11 & .61 & & \\
\hline & $\mathrm{m} 12$ & .59 & & \\
\hline & $\mathrm{m} 13$ & .67 & & \\
\hline & m14 & .56 & & \\
\hline & $\mathrm{m} 17$ & .49 & & \\
\hline & $\mathrm{m} 20$ & .56 & & \\
\hline \multirow{5}{*}{ Pes etmeme ve azim } & $\mathrm{m} 1$ & & .58 & \\
\hline & $\mathrm{m} 2$ & & .69 & \\
\hline & $\mathrm{m} 4$ & & .78 & \\
\hline & $\mathrm{m} 10$ & & .51 & \\
\hline & $\mathrm{m} 21$ & & .45 & \\
\hline \multirow{8}{*}{$\begin{array}{c}\text { Farklı çözüm stratejileri } \\
\text { inancı }\end{array}$} & $\mathrm{m} 6$ & & & .57 \\
\hline & $\mathrm{m} 15$ & & & .53 \\
\hline & $\mathrm{m} 16$ & & & .42 \\
\hline & $\mathrm{m} 18$ & & & .63 \\
\hline & m19 & & & .61 \\
\hline & $\mathrm{m} 22$ & & & .30 \\
\hline & Açıklanan Varyans & $\% 30,073$ & $\% 6,815$ & $\% 5,758$ \\
\hline & Toplam Varyans & & $\% 42,646$ & \\
\hline
\end{tabular}

AFA sonucunda oluşan üç faktörlü (boyutlu) modelin yapı geçerliği için DFA uygulanarak analiz yapılmıştır. DFA analizi sonucunda $\chi^{2 / d f}$ (Chi-Square/Degree of Freedom), RMSEA (Root Mean Square Error of Approximation), NFI (Normed Fit Index), CFI (Comparative Fit Index), AGFI (Adjusted Goodness of Fit Index), GFI (Goodness of Fit Index) değerleri incelenmiştir. Buna göre 22 maddelik ölçeğe DFA uygulanması sonucunda elde edilen değerler: $\chi^{2 / d f}=2.184(p=.000)$; RMSEA=0.063; $\mathrm{NFI}=0.917 ; \mathrm{CFI}=0.921 ; \mathrm{AGFI}=0,83 ; \mathrm{GFI}=0,921$ şeklindedir. DFA modelinde ortaya çıkan yapıya Şekil 3'te yer verilmiştir.

DFA analizinden sonra $\chi^{2 / d f}=2.184$ şeklinde bulunmuştur. $\chi^{2}$ değerinin serbestlik derecesine oranının 5'e eşit ya da 5'in altında bir değere sahip olması, modelin kabul edilebilir bir düzeyde olduğu şeklinde yorumlanabilir (Kline, 2010). Dolayısıyla bu çalışmada yer alan 2.184 değeri kabul edilebilir düzeydedir. RMSEA değerinin .050 ile .080 arasında olması modelin kabul edilebilir boyutta olduğunu gösterir. Dolayısıyla bu ölçekte yer alan RMSEA değerinin .063 olması kabul edilebilirlik düzeyindedir. Yine Kline'e göre (2010) NFI ve CFI değerlerinin .90'a eşit veya üzerinde olması bu modelin kabul edilebilirliğini ifade etmektedir. Yani literatürde yer alan ilgili değerlere bakıldığında bu çalışmanın DFA'dan elde edilen veriler ölçeğin kabul edilebilirlik düzeyinde olduğunu göstermektedir.

Şekil 3'te DFA'nın path grafiği verilmiştir. DFA path grafiğinde standartize edilmiş katsayılarla gözlenen değişkenin gizli değişken üzerindeki yükünün 
minimum .20 olması gerekir (Avşar, 2007). Bu bağlamda Şekil 3 incelendiğinde her bir faktörü temsil eden maddelere ait faktör yükleri incelendiğinde .21 ile .94 arasında değerler aldığ1 görülmektedir. Örneğin M9 ile M18 maddelerinin madde faktör ilişkisinin düşük düzeyde olduğu, M10 maddesine ait madde faktör ilişkisinin yüksek düzeyde olduğu söylenebilir. Şekil 3 'te yer alan verilerin faktörlere göre yorumlanmasında (ön hazırlık inancı, pes etmeme ve azim, farklı çözüm stratejileri inancı faktörleri) faktörler arasında çizilen çift yönlü eğri oklar ve bu okların üzerinde yazan değerler dikkate alınmalıdır. Örneğin pes etmeme boyutu faktörü ile farklı çözüm stratejileri boyutu faktörü arasındaki çift yönlü ok üzerinde yer alan .65 değerine göre, pes etmeme faktörü içerisindeki maddeye verilen cevapların herhangi bir değişime uğraması farklı çözüm stratejileri faktörünü, farklı çözüm stratejileri faktörü içerisindeki maddeye verilen cevapların herhangi bir değişime uğraması da pes etmeme stratejileri faktörünü pozitif yönde ve yüksek oranda etkileyebileceğini söyleyebiliriz. Diğer faktörler arasında (ön hazırlık-pes etmeme, ön hazırlık-farklı çözüm stratejileri) ise orta düzeyde bir değişim olacağını da ekleyebiliriz. Çelik (2009) hata faktörlerinin gözlenen değişkenler ile gizli değişkenler arasındaki ilişkinin bozulmalarına sebep olan hatalar olduğunu ifade etmiştir. Dolayısıyla eğer gözlenen değişken hata içeriyorsa Şekil 3'te yer alan değişkenin sağında yer alan regresyon katsayıları da zayıf olmaktadır. Genel olarak Şekil 3’ü incelediğimizde söz konusu bozulmaya sebep olabilecek hata faktörünün bulunmadığını söyleyebiliriz. 


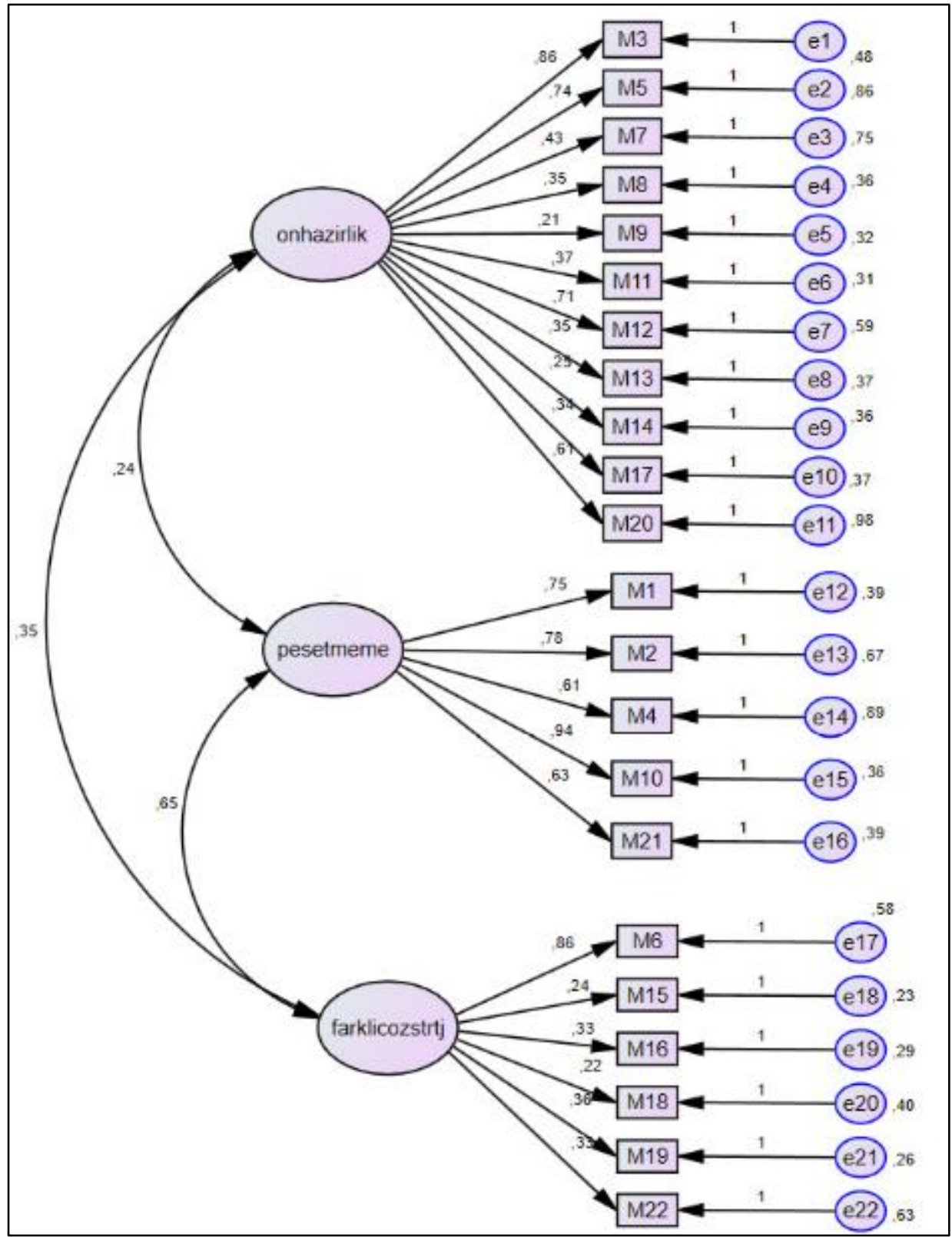

Şekil 3. DFA path diyagramı

\section{Ölçeğin Güvenirlik Çalışmasından Elde Edilen Bulgular}

Ölçeğin güvenirliği hakkında yorum yapabilmek için Cronbach Alpha güvenirlik katsayısı hesaplanmıştır. Hem ölçeğin geneline yönelik hem de her bir faktöre yönelik Cronbach Alpha güvenirlik katsayısı ayrı ayrı hesaplanmıştır. Daha sonra ölçekte ölçülmesi istenen her bir inanç özelliğini incelemek amacıyla madde toplam korelasyonuna bakılmıştır. Elde edilen verilere Tablo 2 'de yer verilmiştir. 
Tablo 2

Madde-Toplam Korelasyonları ve Cronbach Alpha Güvenirlik Katsayıları

\begin{tabular}{|c|c|c|c|c|}
\hline Faktörler/Maddeler & $\bar{X}$ & ss & $\begin{array}{c}\text { Madde-Toplam } \\
\text { Korelasyonu }\end{array}$ & $\begin{array}{c}\text { Madde } \\
\text { Çıkarıldığında } \\
\text { Cronbach Alpha } \\
\text { Güvenirlik Katsayısı }\end{array}$ \\
\hline \multicolumn{5}{|c|}{ Ön Hazırlı İnancl $(a=0,82)$} \\
\hline $\mathrm{m} 3$ & 4.06 & .82 & 320 & .602 \\
\hline $\mathrm{m} 5$ & 3.50 & .98 & .425 & .623 \\
\hline $\mathrm{m} 7$ & 3.54 & .88 & .315 & .647 \\
\hline $\mathrm{m} 8$ & 4.24 & .78 & .516 & .578 \\
\hline $\mathrm{m} 9$ & 4.13 & .71 & .410 & .598 \\
\hline $\mathrm{m} 11$ & 3.18 & 1.11 & .322 & .694 \\
\hline $\mathrm{m} 12$ & 3.62 & .83 & .326 & .612 \\
\hline $\mathrm{m} 13$ & 4.09 & .79 & .582 & .577 \\
\hline $\mathrm{m} 14$ & 3.95 & .76 & .313 & .606 \\
\hline $\mathrm{m} 17$ & 3.82 & 1.09 & .321 & .717 \\
\hline $\mathrm{m} 20$ & 3.48 & 1.02 & .328 & .641 \\
\hline \multicolumn{5}{|c|}{ Pes Etmeme ve Azim $(a=0,89)$} \\
\hline $\mathrm{m} 1$ & 4.37 & .86 & .430 & .478 \\
\hline $\mathrm{m} 2$ & 3.90 & .94 & .406 & .495 \\
\hline $\mathrm{m} 4$ & 3.44 & 1.01 & .368 & .705 \\
\hline $\mathrm{m} 10$ & 4.20 & .75 & .387 & .502 \\
\hline $\mathrm{m} 21$ & 4.32 & .72 & .321 & .523 \\
\hline \multicolumn{5}{|c|}{ Farklı Çözüm Stratejileri İnancı $(a=0,85)$} \\
\hline $\mathrm{m} 6$ & 3.06 & .87 & .398 & .658 \\
\hline m15 & 4.15 & .71 & .451 & .320 \\
\hline $\mathrm{m} 16$ & 4.25 & .78 & .448 & .345 \\
\hline $\mathrm{m} 18$ & 4.00 & .80 & .328 & .426 \\
\hline m19 & 4.30 & .77 & .443 & .438 \\
\hline $\mathrm{m} 22$ & 3.74 & .90 & .422 & .674 \\
\hline
\end{tabular}

Cronbach Alpha güvenirlik katsayısının .60 ve .60 'ın üzerinde değer alması o ölçeğin güvenirliğini karşıladığı anlamına gelmektedir (Büyüköztürk, 2010). Bu çalışmada yer alan ölçeğin tümünden elde edilen Cronbach Alpha güvenirlik katsayısı $.88^{\prime}$ dir. Tablo 2 ' de görüldüğgu gibi alt faktörlerde yer alan Cronbach Alpha güvenirlik katsayıları ön hazırlık inancı faktöründe .82, pes etmeme ve azim faktöründe .89 , farklı çözüm stratejileri inancı faktöründe .85 olarak bulunmuştur. Büyüköztürk'e göre (2010) hesaplanan bu güvenirlik katsayıları geometrik düşünme alışkanlıklarına yönelik inanç ölçeğinin kabul edilebilir düzeyde güvenilir olduğu söylenebilir. Ölçekte yer alan maddelerin istenilen özellikleri ölçüp ölçmediği hakkında yorumlama yapmak için madde analiz değerlerine bakılmıştır. Yani madde analiz değerlerinin .30 ve .30 'un üzerinde olması ölçekte yer alan maddelerin geçerli olduğunun bir göstergesidir (Field, 2005). Bu kapsamda Tablo 2'de görüldüğğ gibi ön hazırlık inancına ait faktörde yer alan madde toplam korelasyonları .32 ile .58 arasında, pes etmeme ve azme ait faktörde yer alan madde toplam korelasyonları .32 ile .43 arasında, farklı çözüm stratejileri inancına ait faktörde yer alan madde toplam korelasyonları ise .32 ile .45 arasında değişmektedir. Bu değerler hazırlanan ölçeğin, ölçmek istediği özellikleri ölçebildiğini göstermektedir. 
Yukarıda verilen analizler neticesinde 6'sı olumsuz 16'sı olumlu toplam 22 maddelik, geometrik düşünme alışkanlıklarına yönelik inançları ortaya çıkaran bir ölçek geliştirilmiştir. Geliştirilen bu ölçek ön hazırlık inancı, pes etmeme ve azim ile farklı çözüm stratejileri inancı şeklinde 3 boyuttan oluşmaktadır.

\section{Tartışma, Sonuç ve Öneriler}

Bu çalışmada geometrik düşünme alışkanlıklarına yönelik inanç ölçeği geliştirilmiştir. Geliştirilen ölçeğin kapsam ve yapı geçerliliği sağlanmıştır. Kapsam geçerliliğini sağlamak amacıyla uzman görüşlerinden faydalanılmıştır. Yapı geçerliğini sağlarken de önce AFA sonra da DFA yapılmıştır. Uygulanan AFA sonrasında \%42.4'ünü açıklayan 22 maddeden ve 3 boyuttan (faktörden) oluşan bir ölçek elde edilmiştir. Bu boyutlar sirasıyla ön hazırlık inanc1 (m3, m5, m7, m8, m9, m11, m12, m13, m14, m17, $\mathrm{m} 20)$, pes etmeme ve azim (m1, m2, m4, m10, m21), farklı çözüm stratejileri inanc1 (m6, $\mathrm{m} 15, \mathrm{~m} 16, \mathrm{~m} 18, \mathrm{~m} 19, \mathrm{~m} 22)$ şeklindedir. Ölçekte yer alan "m8- Karmaşık bir geometri problemi ile karşılaşıldığında problemin ne olduğunu belirlemeye yardımcı olacak bilgileri toplamak için bir strateji geliştirilmelidir, m9- Bir geometri problemine yönelik çözüme başlamadan önce çözümün nasıl yapılacağı üzerinde düşünülmelidir, m11- Bir geometri problemine yönelik çözüme başlamadan önce çözümün nasıl yapılacă̆ı üzerinde düşünülmelidir" şeklindeki maddeler ön hazırlık inancı boyutuna girmektedir. "m1- En zor geometri problemlerinin de üzerinde ısrarla çalışılırsa doğru sonuca ulaşılabilir, m2- Bir geometri problemi ile karşılaşıldı̆̆ında başka konuya geçmeden önce o problem üzerinde düşünmek gerekir, m10- Geometri problemine ilişkin bir karar vermeye çalışırken her seçeneğin sonuçları birbiriyle karşılaştırılarak karar verilmelidir" şeklindeki maddeler pes etmeme ve azim boyutuna girmektedir. Son olarak farklı çözüm stratejileri inancı boyutunda ise "m16- Verilen geometri probleminin çözülemediği durumlarda başkalarını çözüm yolları araştırılmalıdır, m18- Bir geometri probleminin çözülemediği durumlarda, bireyler grup arkadaşlarının görüşlerini dikkate almalıdır, m19- Bir takımın parçası olunan ve başkalarıyla iletişim kurulabilen ortamlar, problem çözme aktivitelerinin en iyi gerçekleştirilebildiğ $i$ ortamlardır" şeklindeki maddeler yer almaktadır. Toplam 22 maddeden oluşan ölçeğin 6 maddesi (m3, m4, m5, m6, m15, m17) olumsuzdur. Olumsuz maddeler "m3- Geometri problemi çözme sürecinde başarılı olunmazsa, bireyin o problemle başa çıkabilme yeteneğinden kuşku duyulur, m4- Zor bir geometri problemi ile karşılaşıldığında, problemi tam anlayabilmek için nasıl bilgi toplanacağına yönelik geniş çaplı düşünmeye gerek yoktur, m15- Bir geometri problemini çözerken kesin kurallar ve talimatları izlemek o çözümü güvenilir yapar ..." şeklindedir.

Ölçekten elde edilen yapıların doğrulama işlemi için de DFA yöntemi uygulanmıştır. DFA'dan elde edilen sonuçlar $\left(x^{2 / d f}=2.184(p=.000) ; R M S E A=0.063\right.$; $\mathrm{NFI}=0.917$; CFI= 0.921; AGFI=0,83; GFI=0,921) şeklindedir. Bu sonuçlar Kline'a (2010) göre kabul edilebilir düzeydedir. Benzer şekilde Aydın-Koçer (2019) tarafından yürütülen çalışmadan elde edilen değerlerin DFA için geçerli olduğu görülmektedir. Yani üç alt boyuttan oluşan ölçeğin geçerli bir yapıya sahip olduğu anlaşılmış ve DFA sonuçları ile de modelin uygun olduğu gözlenmiştir.

Ölçeğin güvenirlik hesaplamaları da bu çalışmada hesaplanmıştır. Geliştirilen geometrik düşünme alışkanlıklarına yönelik inanç ölçeğinden elde edilen güvenirlik katsayıları ölçeğin tamamı için a=.88'dir. Büyüköztürk'e (2010) göre bu güvenirlik katsayısı ölçek geliştirme çalışmaları için yeterli düzeydedir. Ayrıca geliştirilen ölçeğin alt boyutlarına (faktörlerine) göre güvenirlik katsayıları incelendiğinde; ön hazırlık 
inanc1 faktöründe .82, pes etmeme ve azim faktöründe .89 , farklı çözüm stratejileri inancı faktöründe .85 şeklindedir. Benzer şekilde Kayan ve Çakıroğlu (2008) ilköğretim matematik öğretmen adaylarının matematiksel problem çözmeye yönelik inançlarını ölçmeye yönelik geliştirdiği ölçekte, güvenirlik katsayılarını kabul edilebilir düzeyde ele almıştır. Ayrıca Büyüköztürk (2010) .60'1n üzerinde güvenirlik katsayılarının kabul edilebilir düzeyde olduğunu vurgulamıştır.

Geometrik düşünme alışkanlıklarının bireylerin geometri başarısı üzerinde etkisi büyüktür (Driscoll vd., 2007; Driscoll vd., 2008; Bülbül ve Güven, 2019; Bülbül ve Güven, 2020). Yine literatürde bireylerin düşünme alışkanlıkları üzerinde o alışkanlıkları kullanabilmeye yönelik inançlarının etkili olduğu ifade edilmiştir (Costa ve Kallick, 2000). Bu iki bulgudan hareketle, bu çalışmada bireylerin geometrik düşünme alışkanlıklarının başarısı üzerinde onların bu alışkanlıklara yönelik inançlarının etkili olabileceği düşünülmüştür. Ancak ilgili literatürde de bu inançları belirli boyutlarla ölçebilecek bir çalışmaya rastlanmamış olması, bu çalışmanın gerekliliğini ortaya koymuştur. Dolayısıyla bu çalışma ile bireylerin geometrik düşünme alışkanlığı inancına yönelik 22 maddelik bir ölçek geliştirilmiştir. Geliştirilen bu ölçeğin ortaokul, lisede ya da üniversitede öğrenim gören öğrencilerin karşılaştı̆̆1 geometri problemlerine ve geometrik düşünme alışkanlıklarına yönelik düşüncelerini, inançlarını belirlemek için kullanılması önerilebilmektedir.

\section{Kaynakça}

Arisa, S. and Hitchens, M. (1998). Teaching world history: The global human experience through time. Indiana: ERIC Clearinghouse for Social Studies/Social Science Education.

Avşar, F. (2007), Doğrulayıcı faktör analizi ve beck depresyon envanteri üzerine bir uygulama (Yayımlanmamış Yüksek Lisans Tezi). Yıldız Teknik Üniversitesi, Fen Bilimleri Enstitüsü, İstatistik Anabilim Dalı, İstanbul.

Aydın-Koçer, P. (2019). Students' tendencies towards learning vocabulary through mobile computer supported colloborative learning (MCSCL)- A scale development study (Unpublished Doctoral Dissertation). Bahçeşehir University, Program of Educational Technology.İstanbul.

Bailin, S. and Case, R. (1999). Conceptualizing critical thinking. Journal of Curriculum Studies, 31(3), 285-302.

Baki, A. (2008). Kuramdan uygulamaya matematik eğitimi (Genişletilmiş 4. Basım). Ankara: Harf Eğitim Yayıncılı̆̆ı.

Ball, D. (1998). Research on teacher learning: Studying how teachers' knowledge changes. Action in Teacher Education, 10(2), 7-24. https:/ / doi.org/10.1080/01626620.1988.10519385

Bergman, D. J. (2007). The effects of two secondary science teacher education program structures on teachers' habits of mind and action (Unpublished Dissertation). Iowa State University, Iowa

Bindak, R. (2005). İlköğretim öğrencileri için matematik kayg1 ölçeği. Fırat Üniversitesi Fen ve Mühendislik Bilimleri Dergisi, 17(2), 442-448.

Bryant, F. B. and Yarnold, P. R. (1995). Principal-components analysis and exploratory and confirmatory factor analysis. In L. G. Grimm \& P. R. Yarnold (Eds.), Reading and understanding multivariate statistics (pp. 99-136). Washington, DC, US: American Psychological Association 
Bülbül, B. Ö. ve Güven, B. (2019). Geometrik düşünme alışkanlıkları ile akademik başarı arasındaki ilişkinin incelenmesi: Matematik öğretmeni adayları örneği. Türk Bilgisayar ve Matematik Eğitimi Dergisi, 10(3), 711-731.

Bülbül, B.Ö. (2016). Matematik öğretmeni adaylarının geometrik düşünme alışkanlıkların geliştirmeye yönelik tasarlanan öğrenme ortamının değerlendirilmesi (Yayımlanmamış doktora tezi). Karadeniz Teknik Üniversitesi, Eğitim Bilimleri Enstitüsü, Trabzon.

Bülbül, B.Ö. ve Güven, B. (2020). Öğretmen adaylarının geometrik düşünme alanlarının değişimi. Pamukkale Üniversitesi Eğitim Fakültesi Dergisi,48, 431-453. doi: $10.9779 /$ pauefd 513220

Büyüköztürk, Ş. (2018). Sosyal bilimler için veri analizi el kitabı. Ankara: Pegem Akademi.

Cohen, L., Manion, L. and Morrison, K. (2002). Research methods in education. London: Routledge and Falmer. https:/ / doi.org/10.4324/9780203224342

Cook, G. E. (1996). Using clinical supervision to promote inquiry. Journal of Staff Development, 7(4), 46-50.

Costa, A. L. and Kallick, B. (2000). Discovering and exploring habits of mind. Alexandria, VA: Association for Supervision \& Currculum Development

Coxford, A. F., Fey, J. T., Hirsch, C. R., Schoen, H. L., Burrill, G., Hart, E. W., and Watkins, A. E. (1998). Contemporary mathematics in context: a unified approach. Implementing the core-plus mathematics curriculum. Chicago: Everyday Learning Corporation.

Cuoco, A., Goldenberg, E. and Mark, J. (1996). Habits of mind: An organizing principle for mathematics curricula. Journal of Mathematical Behavior, 15(4), 375402. https:/ / doi.org/10.1016/S0732-3123(96)90023-1

Çelik, H. E. (2009). Yapısal eşitlik modellemesi ve bir uygulama: genişletilmiş online alışveriş kabul modeli (Yayımlanmamış doktora tezi). Eskişehir Osmangazi Üniversitesi, Fen Bilimleri Enstitüsü, İstatistik Anabilim Dalı, Eskişehir.

Driscoll, M. J., DiMatteo, R. W., Nikula, J. and Egan, M. (2007). Fostering geometric thinking: A guide for teachers grades 5-10. Portsmouth, NH: Heinemann

Driscoll, M. J., DiMatteo, R. W., Nikula, J., Egan, M., Mark, J. and Kelemanik, G. (2008). The Fostering Geometric Thinking Toolkit: A Guide for Staff Development. Portsmouth, NH: Heinemann

Field, A. (2005). Discovering statistics using SPSS. London: Sage Publications.

Goldenberg, E. P. (1996). "Habits of Mind" as an organizer for the curriculum. Journal of Education, 178(1), 13-34. https:// doi.org/10.1177/002205749617800102

González, G. and Herbst, P. G. (2006). Competing arguments for the geometry course: Why were American high school students supposed to study geometry in the twentieth century?. International Journal for the History of Mathematics Education, 1(1).

Grouws, D. A. (1996). Critical issues in problem solving instruction in mathematics. In D. Zhang, T. Sawada, \& J. P. Becker (Eds.), Proceedings of the China-Japan-U.S. seminar on mathematical education (pp. 70-93). Carbondale, IL: Board of Trustees of Southern Illinois University 
Hinkin, T. R. (1995), A Review of Scale Development Practices In the Study of Organizations, Journal of Management, 21(5),967-988. https:/ / doi.org/10.1177/014920639502100509

Jacobbe, T. and Millman, R. S. (2009). Mathematical habits of the mind for preservice teachers. School Science and Mathematics, 109(5), 298-302. https:/ / doi.org/10.1111/j.1949-8594.2009.tb18094.x

Jones, V. R. (2014). Habits of mind: developing problem-solving strategies for all learners Children's Technology and Engineering, 19(2), 24-26

Kaiser, H. F. (1960). The application of electronic computers to factor analysis. Educational and Psychological Measurement, 20(1), 141-151. https:/ / doi.org/10.1177/001316446002000116

Kayan, F. ve Çakıroğlu, E. (2008). İlköğretim matematik öğretmen adaylarının matematiksel problem çözmeye yönelik inançları. Hacettepe Üniversitesi Eğitim Fakültesi Dergisi, 35, 218-226.

Kline, R. B. (2010), Principles and Practice of Structural Equation Modeling (3rd.Ed.). New York: Guilford Press

Leikin, R. (2007). Habits of mind associated with advanced mathematical thinking and solution spaces of mathematical tasks. In the Proceedings of the Fifth Conference of the European Society for Research in Mathematics Education (pp. 2330-2339). Larnaca, Cyprus.

Lim, K. H. and Selden, A. (2009). Mathematical habits of mind. In S. L. Swars, D. W. Stinson and S. Lemons-Smith (Eds.). Proceedings of the 31st annual meeting of the North American Chapter of the International Group for the Psychology of Mathematics Education. Atlanta, GA: Georgia State University

Marzano, R. J., Pickering, D., \& McTighe, J. (1993). Assessing student outcomes: Performance assessment using the dimensions of learning model. Alexandria: Association for Supervision and Curriculum Development

National Council of Teachers of Mathematics. (2000). Principles and standards for school mathematics. Reston, VA: National Council of Teachers of Mathematics

Richardson, V. (1996). The role of attitudes and beliefs in learning to teach. In J. Sikula (Ed.), Handbook of Research on Teacher Education (2nd ed., pp.102-119). New York: Macmillan.

Schoenfeld, A. H. (1992). Learning to think mathematically: Problem solving, metacognition, and sense making in mathematics. In D. A. Grouws (Ed.), Handbook of research on mathematics teaching and learning (pp. 334-370). New York: Macmillan Publishing Company

Sher, B. (1992). Developing a scope and sequence in science for high ability learners K-8 Developing science curriculum for high ability learners K-8. Virginia: College of William and Mary, Williamsburg

Soylu, Y. ve Soylu, C. (2006). Matematik derslerinde başarıya giden yolda problem çözmenin rolü. İnönü Üniversitesi Eğitim Fakültesi Dergisi. 7(11), 97-111.

Tabachnick, B. G. and Fidell, L. S. (2001), Using Multivariate Statistics (Fourth Edition). Boston: Ally and Bacon

VanTassel-Baska, J. (1998). Planning science programs for high ability learners. Virginia: ERIC Clearinghouse on Disabilities and Gifted Education 
Volkmann, M. J. and Eichinger, D. C. (1999). Habits of mind: Integrating the social and personal characteristics of doing science into the science classroom. School Science and mathematics, 99(3), 41-47. https:/ / doi.org/10.1111/j.19498594.1999.tb17462.x

Wilkins, J., and Brand, B. (2004). Change in pre-service teachers' beliefs: An evaluation of a mathematics methods course. School Science $\mathcal{E}$ Mathematics, 104(5), 226-232. https:/ / doi.org/10.1111/j.1949-8594.2004.tb18245.x

\section{Ekler \\ Ek 1. Geometrik Düşünme Alışkanlığı İnanç Ölçeği}

\begin{tabular}{|c|c|c|c|c|c|}
\hline Ölçek Maddeleri & 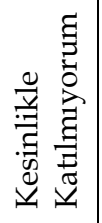 & 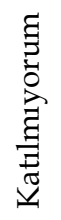 & 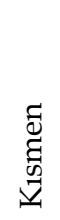 & 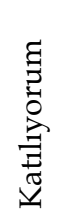 & 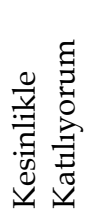 \\
\hline $\begin{array}{l}\text { *1. Geometri problemi çözme sürecinde başarılı olunmazsa, bireyin o } \\
\text { problemle başa çıkabilme yeteneğinden kuşku duyulur. }\end{array}$ & & & & & \\
\hline $\begin{array}{l}\text { *2. Zor bir geometri problemi ile karşılaşıldığında, problemi tam } \\
\text { anlayabilmek için nasıl bilgi toplanacağına yönelik geniş çaplı düşünmeye } \\
\text { gerek yoktur. }\end{array}$ & & & & & \\
\hline $\begin{array}{l}\text { 3. Bir geometri problemi çözüldükten sonra, yapılan çözüm tekrar } \\
\text { incelenmeli ve sonuç kontrol edilmelidir. }\end{array}$ & & & & & \\
\hline $\begin{array}{l}\text { 4. Bir geometri problemi çözülemediğinde, farklı kaynaklardan (kitap, } \\
\text { internet, arkadaşlarına sorma gibi) yararlanarak tekrar çözüm üzerinde } \\
\text { düşünülmelidir. }\end{array}$ & & & & & \\
\hline $\begin{array}{l}\text { 5. Karmaşık bir geometri problemi ile karşılaşıldığında problemin ne } \\
\text { olduğunu belirlemeye yardımcı olacak bilgileri toplamak için bir strateji } \\
\text { geliştirilmelidir. }\end{array}$ & & & & & \\
\hline $\begin{array}{l}\text { 6. Bir geometri problemine yönelik çözüme başlamadan önce çözümün nasıl } \\
\text { yapılacağı üzerinde düşünülmelidir. }\end{array}$ & & & & & \\
\hline $\begin{array}{l}\text { 7. Bir geometri probleminin sonucuna ulaşıldıktan sonra, yapılan çözüm } \\
\text { tekrar kontrol edilmelidir. }\end{array}$ & & & & & \\
\hline $\begin{array}{l}\text { 8. Bir geometri probleminin çözülemediği durumlarda bireyler, farklı } \\
\text { fikirleri de göz önünde bulundurarak çözümü o fikirler doğrultusunda } \\
\text { düşünmelidir. }\end{array}$ & & & & & \\
\hline 9. Bir geometri problemini çözerken o probleme farklı açılardan bakılmalıdır. & & & & & \\
\hline $\begin{array}{l}\text { *10. Verilen herhangi bir geometri probleminde, herkes aynı yöntemi } \\
\text { kullanmalıdır. }\end{array}$ & & & & & \\
\hline $\begin{array}{l}\text { 11. Bir geometri probleminin sonucuna ulaşırken kullanılan çözüm yolları } \\
\text { başarısız ise bunların neden başarısız olduğu araştırılmalıdır. }\end{array}$ & & & & & \\
\hline $\begin{array}{l}\text { 12. Bir geometri probleminin çözümüne başlamadan önce, çözüme yönelik } \\
\text { plan yapılmalıdır. }\end{array}$ & & & & & \\
\hline $\begin{array}{l}\text { 13. Farklı çözüm stratejilerini uygulamaya imkân veren geometri problemleri } \\
\text { üzerinde çalışmak, bireylerin probleme farklı açllardan bakabilmesini sağlar. }\end{array}$ & & & & & \\
\hline $\begin{array}{l}\text { 14. En zor geometri problemlerinin de üzerinde ısrarla çalışılırsa doğru } \\
\text { sonuca ulaşılabilir. }\end{array}$ & & & & & \\
\hline $\begin{array}{l}\text { 15. Bir geometri problemi ile karşılaşıldığında başka bir probleme geçmeden } \\
\text { önce o problem üzerinde düşünmek gerekir. }\end{array}$ & & & & & \\
\hline $\begin{array}{l}\text { *16. Zor bir geometri problemi ile karşılaşıldığında tek bir yoldan çözüme } \\
\text { ulaşılamıyorsa o problem yanlıştır. }\end{array}$ & & & & & \\
\hline $\begin{array}{l}\text { 17. Geometri problemine ilişkin bir karar vermeye çalışırken her seçeneğin } \\
\text { sonuçları birbiri ile karşılaştırarak karar verilmelidir. }\end{array}$ & & & & & \\
\hline $\begin{array}{l}\text { *18. Bir geometri probleminin tek bir çözümünün olması, o problemin doğru } \\
\text { çözüldüğünü göstermez. Bu yüzden farklı çözüm stratejileri geliştirilerek } \\
\text { problem çözülmelidir. }\end{array}$ & & & & & \\
\hline
\end{tabular}




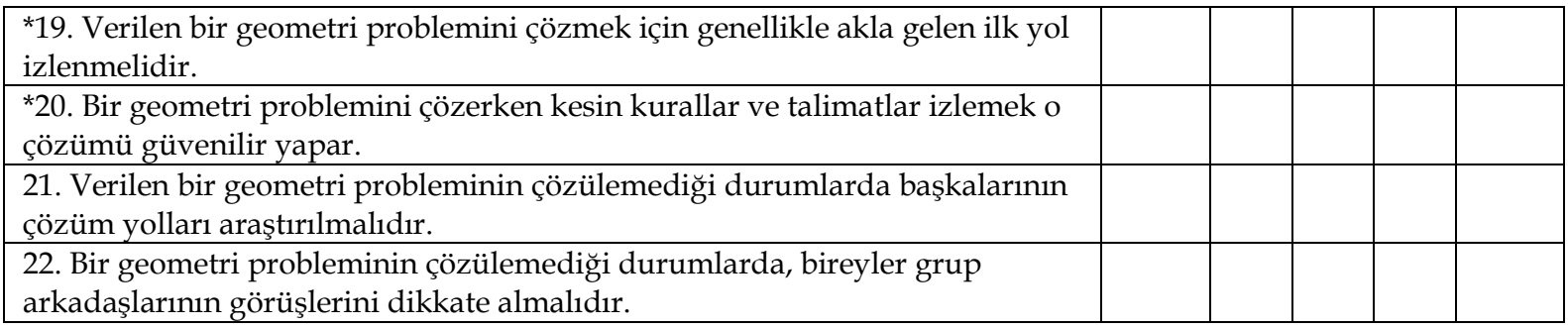

* Geometrik düşünme alışkanlıklarına yönelik olumsuz inançları göstermektedir.

\section{Summary}

\section{Introduction}

One of the main goals of geometry education is to raise individuals who can solve the encountered problems (NCTM, 2000). Individuals tend to use some mental thinking habits during problem solving. These habits are expressed as habits of mind in literature. These habits are expressed as a tendency to overcome the problem when individuals encounter a problem that can not be solved directly (Costa and Kallick, 2000; Jones, 2014). In order to be successful in geometry, it is necessary to have some habits of mind besides being a good problem solver. These habits, which are expressed as geometric habits of mind, can also be regarded as the solution orientations that individuals employ in problem solving process. In other words, the better individuals have geometric habits of mind, the more successful they will be in geometry achievements and geometry problem solving process (Bülbül ve Güven, 2019; Bülbül ve Güven, 2020; Driscoll, DiMatteo, Nikula ve Egan, 2007; Driscoll, DiMatteo, Nikula, Egan, Mark ve Kelemanik, 2008). However, in some cases, individuals may have difficulties in achieving the desired geometry success even though they have geometric habits of mind skills. At this stage, students' belifs of geometric habits of minds cometo the fore. Bülbül (2016) explained affective factors that affect geometric habits of mind as stand firm, managed sense, establish empathy, wondering, flexibility, openness to learning, skepticism, perseverance and self-discipline, prejudice. Literature shows that; no matter how frequent the students use their geometric habits of mind, as their problem-solving beliefs decrease, their level of use of these habits will also decrease (Driscoll et al., 2007; Driscoll et al., 2008). In this respect, revealing students' affective beliefs about habits of minds will ensure that their thinking habits take an important place in the development dimension. Although geometric habits of mind beliefs have an important role in the success of geometry and the effective use of GHoM, a beliefs scale has not been proposed in the literature. Therefore, this study aimed to develop a scale that reveals the beliefs about geometric habits of mind of prospective mathematics teachers.

\section{Method}

This study is a scale development study. While developing the scale, the steps were followed respectively, item pooling, expert opinion, factor analysis and reliability calculation. At the stage of collecting the theoretical data required for the research, a large-scale literature review about geometric habits of mind and beliefs for problem solving has been made. Later, an item pool was prepared for geometric habits of mind beliefs and the prepared items were appropriate for their purpose. In addition, paying 
attention to the fact that each item in item pool does not contain more than one feature and is measurable, an item pool containing 38 items was created. The created item pool was examined by experts from the field of mathematics education, measurement and evaluation. Items that are not understood and do not reflect what is intended to be measured have been revised by expert opinions. As a result of all these procedures, a draft scale was prepared consisting of 38 items. Draft scale items were applied to a total of 296 prospective mathematics teachers. After the application, exploratory factor analysis (EFA) and comfirmatory factor analysis (CFA) were performed. In addition, Cronbach Alpha reliability coefficients were calculated separately for both the whole and each dimension of the scale.

\section{Results}

In this study, a geometric habits of mind beliefs scale was developed. Content validity and construct validity of the developed scale were provided. Expert opinions were used to ensure content validity. In order to ensure the construct validity, first EFA and then CFA were performed. After the EFA was applied, a scale consisting of 22 items and three dimensions (preliminary belief, stand firm and resolution and beliefs of different solution strategies) was obtained, explaining $42.4 \%$ of it. CFA analysis method was used for the verification of the structures obtained from the scale. The results obtained from CFA are as follows: $\left(\chi^{2 / d f}=2.184(p=.000)\right.$; RMSEA=0.063; NFI= 0.917; $\mathrm{CFI}=0.921 ; \mathrm{AGFI}=0,83 ; \mathrm{GFI}=0,921$ ). The reliability calculations of the scale were also calculated in this study. The Cronbach's Alpha reliability coefficient for the complete scale is found to be .92. Cronbach's Alpha reliability coefficients of the subfactors are calculated as $.82, .89$ and .85 respectively. The results obtained from both EFA and DFA show that the scale is acceptable.

\section{Discussion}

In this study, a geometric habits of mind beliefs scale consisting of 22 items was developed. This developed scale consists of three dimensions such as preliminary belief, stand firm and resolution and beliefs of different solution strategies. The validity and reliability studies of this scale were carried out. The dimensions of the scale were determined and the relationships between these dimensions were revealed by EFA and CFA analyzes. For example, in this study a high level of relationship was found between preliminary belief and beliefs of different solution strategies $(r=.65)$. When the related literature is reviewed, it is seen that a relationship of .65 obtained as a result of CFA is an acceptable level (Aydın-Koçer, 2019; Kline, 2010). The Cronbach's Alpha reliability coefficient for the complete scale is .92. Cronbach's Alpha reliability coefficients of the sub-factors are calculated as .82, .89 and .85 respectively. Büyüköztürk (2010) emphasized that the reliability coefficients above are at an acceptable level.

\section{Pedagogical Implications}

Geometric habits of mind are an important factor affecting students' geometry success. Similarly, beliefs about geometric habits of mind affect students' geometric habits of mind. Therefore, before teaching students geometry lessons, it is very important to determine their beliefs of geometric habits of mind and to prepare learning environments for these determined beliefs. Teachers can apply the beliefs of geometric 
habits of mind scale to their students created as a result of this study. In other words, teachers may use this scale in both geometry and mathematics lessons to find out their students' beliefs of geometric habits of mind. So, teachers can design their lessons based on these beliefs they identify.

\section{Araştırmanın Etik Taahhüt Metni}

Yapılan bu çalışmada bilimsel, etik ve alıntı kurallarına uyulduğu; toplanan veriler üzerinde herhangi bir tahrifatın yapılmadığı, karşılaşılacak tüm etik ihlallerde "Cumhuriyet Uluslararası Eğitim Dergisi ve Editörünün" hiçbir sorumluluğunun olmadığı, tüm sorumluluğun Sorumlu Yazara ait olduğu ve bu çalışmanın herhangi başka bir akademik yayın ortamına değerlendirme için gönderilmemiş olduğu sorumlu yazar tarafından taahhüt edilmiştir.

\section{Authors' Biodata/Yazar Bilgileri}

Buket Özüm BÜLBÜL, lisans öğrenimini Karadeniz Teknik Üniversitesi, Fatih Eğitim Fakültesi, İlköğretim Matematik Öğretmenliği bölümünde tamamlamıştır. Doktorasını aynı üniversitede Matematik Eğitimi alanında tamamlamıştır. Yazar çalışmalarına geometri öğretimi, geometrik düşünme alışkanlıkları, problem çözme, bilgisayar destekli matematik eğitimi, öğretmen eğitimi alanlarında devam etmekte olup farklı ulusal projelerde görev almaktadır. Manisa Celal Bayar Üniversitesi Eğitim Fakültesi'nde Dr. Öğr. Üyesi olarak görevine devam etmektedir.

Buket Özüm Bülbül, graduated from Mathematics Education department of Karadeniz Technical University and completed her doctoral program at the same university. She continues her studies in the areas of geometry teaching, geometric habits of mind, problem solving, computer aided mathematics education and teacher training. She has took part in different national projects on teacher education. She is working as Asist. Prof. in Manisa Celal Bayar University, Faculty of Mathematics Edcucation.

Bülent GÜVEN, lisans öğrenimini Karadeniz Teknik Üniversitesi, Fatih Eğitim Fakültesi, Matematik Öğretmenliği programında tamamlamıştır. Yüksel lisans Eğitimini Karadeniz Teknik Üniversitesi, Fen Bilimleri Enstitüsü Matematik Eğitimi alanında, doktorasını ise aynı üniversitede Matematik Eğitimi alanında tamamlamıştır. Yazar çalışmalarına geometri öğretimi, bilgisayar destekli matematik, dinamik geometri yazılımları, problem çözme alanlarında devam etmekte olup farklı ulusal projelerde görev almaktadır. Trabzon Üniversitesi, Fatih Eğitim Fakültesi'nde Prof. Dr. olarak görevine devam etmektedir.

Bülent Güven, graduated from Mathematics Education department of Karadeniz Technical University and completed his MA and doctoral program at the same university. He continues his studies in the areas of geometry, computer aided mathmematics, dynamic geometry softwares, problem solving. He has took part in different national projects. He is working as Prof. Dr. at Trabzon University, Fatih Faculty of Education. 